\title{
Effectiveness of monetary policy transmission in Indonesia
}

\author{
Muhammad Khoirul Fuddin ${ }^{1}$ \\ ${ }^{1}$ Department of Economics, Universitas Muhammadiyah Malang, Malang, Indonesia \\ e-mail: khoirul.fuddin@gmail.com
}

Article Info

\section{Article history:}

Received : 2 July 2014

Accepted : 10 August 2014

Published : 1 October 2014

\section{Keywords:}

policy transmission mechanism, monetary policy, Vector Error Correction Model

\section{JEL Classification:}

E51, E52, E53

DOI:

http://dx.doi.org/10.20885/ejem .vol6.iss $2 . \operatorname{art5}$

\begin{abstract}
This study discusses the channel of monetary policy transmission mechanism of money, credit, interest rate and exchange rate in Indonesia. The effectiveness of the transmission mechanism of monetary policy in Indonesia can be described and explained by the ultimate target object in Indonesia, specifically economic growth and inflation. The analytical tool used in this study is Vector Error Correction Model (VECM) which uses impulse response and variance decomposition in determining the effectiveness of monetary policy transmission mechanism. The results explain that the credit channel is considered effective in explaining economic growth and the interest rate channel is effective in explaining inflation found in Indonesia.
\end{abstract}

\section{Abstrak}

Penelitian ini membahas mengenai saluran mekanisme transmisi kebijakan moneter uang, kredit, suku bunga dan nilai tukar di Indonesia. Efektifitas mekanisme transmisi kebijakan moneter di Indonesia dapat digambarkan dan dijelaskan dengan variabel target utama kebijakan moneter di Indonesia, khususnya pertumbuhan ekonomi dan inflasi. Alat analisis yang digunakan dalam penelitian ini adalah Vector Error Correction Model (VECM) yang menggunakan respon impuls dan dekomposisi varians dalam rangka menentukan efektivitas mekanisme transmisi kebijakan moneter. Hasil menjelaskan bahwa saluran kredit dianggap paling efektif dalam menjelaskan pertumbuhan ekonomi dan jalur suku bunga dianggap paling efektif dalam menjelaskan inflasi yang ditemukan di Indonesia.

\section{Introduction}

Transmission mechanism of monetary policy is the channel that describes how the ultimate goal of a state object can be achieved effectively. Each channel on the monetary policy transmission mechanism is mutually dependent and intertwined with each other. Financial globalization in recent years has affected the monetary transmission mechanism, either by changing the overall impact of monetary policy that has previously been set or change the transmssion line located in a country. Movement of capital and the rapid advancement of technology and the emergence of increasingly sophisticated financial products pose new challenges for a country's macroeconomic and simultaneously it is related to the monetary policyimplications .

Meanwhile, the structural changes associated with increased globalization process provide a range of changes to the transmission mechanism of monetary policy in achieving the ultimate goal. Today the development in understanding the transmission mechanism of monetary policy has become one of the pressing issues for policy makers and researchers in recent years.

Transmission mechanism of monetary policy is an interesting topic and a lot 
of debate. Debate and the topic is often discussed, such as whether using monetary policy would achieve country's monetary goals. If the answer is yes, then the next question is what specific transmission mechanism to achieve that goal. There are various paths thatc an be used in the transmssion mechanism of monetary policy are: channel of money, credit channel, the interest rate channel, exchange rate channel, asset price channel and the expectations channel. Of the six channes are not all the paths used by Indonesia. A country will choose the path of the transmission mechanism of monetary policy in accordance with the ultimate object to be achieved.

Each state has a different mechanism pathway. Malaysia focused on the mechanisms of transmission lines in exchange rates, interest rates and asset prices, while credit is considered less (Poon, 2010). Exchange rate channel is considered to be more influential on Malaysian trade which will have an impact on economic growth. Interest rate influences the investment climate in the country, while the price of an asset is considered to affect consumption patterns that will ultimately have an impact on real GDP.

Guinigundo (2008) said that the Philippines has the ultimate goal of monetary that is inflation targeting. Some of the transmission mechanism are used mainly by the Philippines in achieving these policies include: (a) the interest rate channel that will have an impact on consumption, investment, demand and the money supply, though limited, (b) the exchange rate channel that impact on international trade, longterm investment, the level of prices and the exchange rate is expected, and (c) track inflation expectations impact on consumption and investment. The recent studies by Aban (2013) who empirically tests the presence of a bank lending channel of monetary policy in the Philippines by explaining that loan growth is affected by monetary policy shocks. Using pooled data regression, it found that loan growth of small banks is more sensitive to shock of monetary policy, thus providing evidence for a bank lending channel in the Philippines.

Chow (2004) says that the path used by Singapore is the exchange rate channel. This is because the effective exchange rate is used as an operational tool announced by the central bank to achieve the expected target. The exchange rate shock that is as monetary policy innovations will be made to control the state of the economy of Singapore. Overall, changes in the exchange rate of Singapore will have much impact to overall monetary variables. Innovation exchange rate is more important source of fluctuations in output, compared with a shock of interest rate in influencing the macro economy of a country.

The financial crisis of 1997 brought a significant change in the Indonesian economy, including the monetary policy transmission mechanism. Before the crisis, the Indonesian economy was in a period of "boom" with the increasing flow of foreign capital. In this situation, the interest rate channel works quite well in the transmission of monetary policy into the deposit and lending rates. However, its effectiveness in influencing the real economy was hampered by the fact that both consumption and investment are not responsive to changes in interest rates due to the economic boom and capital adequacy. This is confirmed by the finding that bank loans before the crisis. It does not affect the bank's ability to access funds from international sources. After the crisis, the economy and the financial system has undergone strutural changes and Indonesia moved to a floating exchange rate system. This will be no doubt that it has fundamental implications for the functioning of the transmission mechanism of monetary policy. Exchange rate movements become clearer in affecting the real economy and prices, whereas some later period the effectiveness of monetary policy to influence the exchange rate has 
been undermined by exchange rate movements which was driven more by noneconomic factors (Goeltom, 2008). In contrast Wulandari (2012) found that the interest rate channel plays more important role in monetary transmission mechanism for maintaining inflation but has limited role in the economic growth. In the other hand, loan channels is more effectively in affecting economic growth in Indonesia.

This paper assesses the importance role of two monetary transmission mechanism channels in managing inflation and contributing to economic growth, by employing Structural Vector Autoregressive (SVAR) model. The monetary transmission channels are interest rate channel and credit-bank lending channel. The model is then solved by implementing forecasting error variance decomposition to investigate the contribution of each variables to both inflation and economic growth.

Based on that fact the researcher is going to discuss the development of transmission mechanism of monetary policy in Indonesia. There are four channes on the transmission mechanism of monetary development policy i.e. the supply of money, credit channel, interest rates, and exchange rates. How is the economic shock influence the economic growth and inflation in Indonesia.

There are a variety of channels that can be used in the transmission mechanism namely money channel, credit channel, the interest rate channel, exchange rate channel, asset price channel and the expectations channel. Each Southeast Asia country choose its channels differently. It can be caused by (i) differences in the effectiveness of the transmission mechanism in each country, (ii) structural transmission mechanism located in each country, (iii) the financial system of each country, (iv) and the openness of the economy (Norman and Schmidtz - Hebbel, 2002).

Research conducted by Maski (2007) analyze whether the interest rate channel is more effective than the path of monetary (2) whether the exchange rate channel is relevant in Indonesia (3) which sector credits is dominant and its effect on inflation. To analyze these problems used Vector Autoregressive (VAR) where the results of the analysis are as follows: bank credit in the agricultural sector has a dominant role on inflation and the inflation responds to credit very quickly. The interest rate channel is said to be effective because nowadays there has been a reversal of the fact that the monetary targets no longer determine the amount of the interest rate but rather the interest rate that determines monetary volatility. The existence of the rapid developments of financial instruments helps to determine the irrelevance of monetary aggregates as a target variable in monetary policy framework. The exchange rate as a target variable is considered less effective because the Indonesian economy is vulnerable to changes in the international economy because. Indonesia adheres to the regime of free foreign exbange control.

Transmission mechanism of monetary policy is one tool that can be used to determine monetary policy that will be applied by the government in determining the progress of a country's economic growth. Transmission mechanism of monetary policy itself has a wide variety of channels that can be used in determining a country's monetary policy. It is designed bya go vernment that is usually not just applied to the present, but is also expected to describe the effect of monetary policy transmission mechanism to the development of a future economy. Indonesia is an emerging market which will try to be a developed country and is able to survive in a global economy. One indicator of advancement and economic growth of a country can be seen with the increase in the output of a country. Rising output of a country itself can be influenced by how effective the monetary policy transmission Mechanism used by a country in economic growth. This article will use 
the channel of monetary policy transmision mechanism of money, credit channel, the interest rate channel and exchange rate channel to access the impact on economic growth. Furthermore it is also to determine which is the most effective channel to economic growth and inflation in Indonesia. The following will be presented scheme framework Indonesian monetary policy transmission mechanism.

\section{Methods}

This paper models the channel of monetary policy transmission mechanism of money, credit, interest rate and exchange rate in Indonesia. The paper will analyze the effectiveness of the transmission mechanism of monetary policy in Indonesia in influencing economic growth and inflation. The analytical tool used in this study is Vector Error Correction Model (VECM) which uses impulse response and variance decomposition. The observation period of this study is 1961-2011. In order to do so, it conducts some stationary tests using Augmented Dickey - Fuller (ADF) test. It also conducts a co-integration test, a test in the form of a dynamic model that aims to determine the possibility of a long-term relationship between the variables used in the study. The detection of the presence of co-integration is done by the method of Johansen.

\section{Results and Discussion}

Stationary test is performed using test Augmented Dickey - Fuller (ADF). The results of the ADF statistic are compared with the critical values developed by MacKinnon. If the ADF t statistic count is smaller than the MacKinnon critical value, then the data is said to be stationary. Conversely, if the value is greater than the calculated ADF MacKinnon critical value, it is said to be stationary. Testing began in the form of unit root level. If at the level of the level of the data used are not stationary, then followed by testing in the form of first difference to the second difference. The test results of the fourth stationary tests can be briefly described in Table 1 . The results shows that the optimal lag in the VECM models are mostly lag 1 .

Co-integration test is a test in the form of a dynamic model that aims to determine the possibility of a long-term relationship between the variables. The detection of the presence of co-integration is done by the method of Johansen. If variables are not co-integrated, then the researcher will apply the stationary VAR after ensuring the same degree. However, the study found that the observed variables experience different levels of stationary. It indicates that all the variables is integrated of order two. Cointegration test is performed using the optimal lag is 1 , which has been done in the previous test. Co-integration test results are presented at Table 2.

Based on the table there is one cointegrated equation at $5 \%$ significance level. This suggests that variables of money channel (M2, lending, GDP, inflation), credit channel (credit, loan rates, deposit rates, GDP, inflation), the interest rate channel (real interest rates, deposit rates, loan interest rates, GDP, inflation), the exchange rate channel (real interest rates, exports, imports, exchange rates, GDP, inflation) have a long-term relationship between the variables.

Table 1: Stationary Test

\begin{tabular}{ll}
\hline Path of MTKM & Stationarity Test Result \\
\hline Channel of Money & $1^{\text {st }}$ Difference \\
Channel of Credit & $2^{\text {nd }}$ Difference \\
Channel of Interest Rate & $1^{\text {st }}$ Difference \\
Channel of Exchange Rate & $1^{\text {st }}$ Difference \\
\hline
\end{tabular}


Table 2: Co-integration Test

\begin{tabular}{lrrrr}
\hline \multicolumn{5}{c}{ Path of Money } \\
\hline Hypothesized No. of CE(s) & Eigen value & Trace Statistic & 0.05 Critical Value & Prob.** \\
\hline None * $*$ & 0.485031 & 57.98182 & 47.85613 & 0.0042 \\
At most $1 *$ & 0.353001 & 31.43591 & 29.79707 & 0.0321 \\
Credit Channel & & & & \\
None * & 0.874901 & 120.4956 & 88.8038 & 0.0000 \\
At most 1* & 0.772069 & 72.68659 & 63.8761 & 0.0075 \\
Interest Rate Channel & & & & \\
None * & 0.956375 & 151.4972 & 88.8038 & 0.0000 \\
At most 1* & 0.858596 & 79.45817 & 63.8761 & 0.0014 \\
Exchage Rate Channel & & & & \\
None * & 0.966222 & 210.6185 & 117.7082 & 0.0000 \\
At most 1* & 0.902053 & 129.3082 & 88.8038 & 0.0000 \\
At most 2* & 0.760391 & 73.54835 & 63.8761 & 0.0062 \\
\hline
\end{tabular}

Table 3: VECM Estimation Result of Money Channel

\begin{tabular}{cccc}
\hline \multicolumn{4}{c}{ Short Term } \\
\hline GDP & INF & M2 & PK \\
$(0.115076)$ & $(-0.729517)$ & $(-0.187311)$ & $(-0.048645)$ \\
{$[1.27407]$} & {$[-3.12794]^{*}$} & {$[-0.68064]$} & {$[-0.59639]$} \\
INF & \multicolumn{2}{c}{ Long Term } & PK \\
$(1.505395)$ & M2 & $(-0.097913)$ \\
{$[6.36979]^{*}$} & \multicolumn{2}{c}{$(-0.944139)$} & {$[-1.02816]$} \\
\hline
\end{tabular}

VECM estimation results for money channel suggest that in the short term there is an error correction 0.115076 (GDP), 0.729517 (INF), -0.187311 (M2) and $0.048645(\mathrm{PK})$. The variable that is statistically significant is only INF. This means that every period errors is corrected by $0.115076 \%$ (GDP), $-0.729517 \%$ (INF), $0.187311 \%$ (M2) and $-0.048645 \%$ (PK) to get to balance shork term and long-term. In the long term suggests that the monetary policy transmission mechanism in which the money channel variables of GDP, INF, M2 and PK are significantly affected by inflation and M2. (Table 3).

VECM estimation results of the credit channel suggest that in the short term, there is an error correction of 0.404776 (GDP), -0.824167 (INF), -0.066054 (PK) and -0.345918 (SBD), 0.404776 (SBP). GDP and SBP are statistically significant. This means that every period errors is corrected by $0.404776 \%$ (GDP), $-0.824167 \%$
(INF), $-0.066054 \%$ (PK) and $-0.345918 \%$ (PK), $-0.345918 \%$ (SBD) and $0.404776 \%$ (SBP) to balance the long and short term. In the long term, the variables of GDP, INF, PK, SBD and SBP are significantly affected by inflation, deposit rates and lending rates, while PK had no significant effect (Table 4).

VECM estimation results of the interest rate channel found that in the short term, there is an error correction 0.002734 (GDP), 0.002242 (INF), -0.002211 (SBD) and -0.345918 (SBP), -0.001760 (SBR). This means that every period errors is corrected by $0.002734 \%$ (GDP), $0.002242 \%$ (INF), $-0.002211 \%$ (SBD) and $-0.345918 \%$ (SBP), $-0.001760 \%$ (SBR) to balance the long-term and short-term. In the long term, the credit channel variables of GDP, INF, SBR SBD and SBP aree significantly influenced by the deposit rates, lending rates and real interest rates, while the inflation had no significant effect on the interest channel variables (Table 5). 
Table 4: VECM Result Estimation of Credit Channel

\begin{tabular}{ccccc}
\hline \multicolumn{5}{c}{ Short Term } \\
\hline GDP & INF & PK & SBD & SBP \\
$(0.404776)$ & $(-0.824167)$ & $(-0.066054)$ & $(-0.345918)$ & $(0.404776)$ \\
{$[2.44301]^{*}$} & {$[-1.5549]$} & {$[-0.36879]$} & {$[-1.56547]$} & {$[-2.36431]^{*}$} \\
INF & & Long Term & & \\
$(1.726313)$ & PK & & SBD & SBP \\
{$[12.1555]^{*}$} & $(0.122653)$ & $(-5.539141)$ & $(6.573644)$ \\
\hline
\end{tabular}

Table 5: Result Estimation of VECM Interest Rate Channel

\begin{tabular}{ccccc}
\hline \multicolumn{5}{c}{ Short Term } \\
\hline GDP & INF & SBD & SBP & SBR \\
$(-0.002734)$ & $(0.002242)$ & $(0.002211)$ & $(0.002099)$ & $(-0.00176)$ \\
{$[-1.55901]$} & {$[0.40231]$} & {$[0.91731]$} & {$[1.57384]$} & {$[-0.49142]$} \\
INF & \multicolumn{2}{c}{ Long Term } & SBP & SBR \\
$(-19.04423)$ & SBD & & $(-797.4871)$ & $(76.26647)$ \\
{$[-0.82485]$} & $(540.3573)$ & {$[-8.58378]^{*}$} & {$[3.8413]^{*}$} \\
\hline
\end{tabular}

Table 6: VECM Estimation Result of Exchange Rate Channel

\begin{tabular}{cccccc}
\hline \multicolumn{6}{c}{ Short Term } \\
\hline GDP & EKS & IMP & INF & NT & SBR \\
$(-0.246319)$ & $(0.10757)$ & $(-0.034142)$ & $(0.212678)$ & $(-19.30662)$ & $(-0.143917)$ \\
{$[-0.82709]$} & {$[0.26356]$} & {$[-0.11928]$} & {$[0.21566]$} & {$[-0.17367]$} & {$[-0.27756]$} \\
EKS & \multicolumn{5}{c}{ Long Term } \\
$(-2.074062)$ & $(2.579574)$ & $(0.557281)$ & $(0.002477)$ & $(1.997745)$ \\
{$[-12.7528]^{*}$} & {$[16.1801]^{*}$} & {$[7.80243]^{*}$} & {$[12.5598]^{*}$} & {$[17.4944]^{*}$} \\
\hline
\end{tabular}

VECM estimation results of the exchange rate channel found that there is an error correction -0.246319 (GDP), 0.107570 (EKS), -0.034142 (IMP), 19.30662 (NT) and -0.143917 (SBR). This means that every period errors is corrected by $-0.246319 \%$ (GDP), $0.107570 \%$ (EKS), $-0.034142 \%$ (IMP), $-19.30662 \%$ (NT) and $0.143917 \%$ (SBR) to balance short term and long-term. In the long term shows that the transmission mechanism of monetary credit channel is significantly affected by exports, imports, inflation, exchange rates and real interest rates (Table 6).

\section{Impulse Response Function}

Impulse Response Function (IRF) is used to describe the movement of the endogenous variable due to any shock. Figure 1 explains the changes in GDP with respect to any monetary shock of GDP itself, INF, M2 and PK. The GDP response positively of shock of INF and deposits with the highest positive response value $0.976225 \mathrm{SD}$ (INF) in period 3 and $0.049671 \mathrm{SD}(\mathrm{PK})$ in period 2. Monetary variables shocks is largely responded in the second period but returned to stagnate after the second period until the period of ten. Thus the growth of the economy as reflected in GDP less likely can be explained through the money variables.

Figure 2 shows the GDP change with respect to credit channel variables of GDP itself, INF, SBD, SBP and PK. The effect GDP, INF and SBP shocks are responded positively by GDP with the highest positive response value 3.382599 SD (GDP) in period 1 and 3.452940 SD (INF) in period 2, and 1.127812 SD (SBP). While 
the shock of SBD is responded negatively by GDP with the highest negative shock value of $-1.846367 \mathrm{SD}$ in period 3. While for the shock of PK had a positive impact of $0.424192 \mathrm{SD}$ in period 3 and -0.675467 SD in period 4. Credit channels shocks are responded almost all in the first period and continued to fluctuate up to 10 period. Thus it could be explained that the Indonesia's economic growth has been centered on the credit activity. The higher is the credit activity, the higher is the growth of the Indonesian economy.

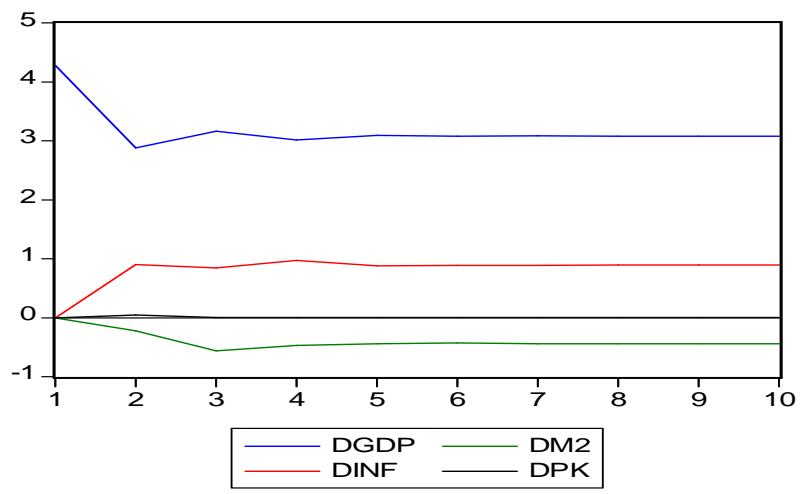

Figure 1: Impulse Response Function of Money Channel to GDP

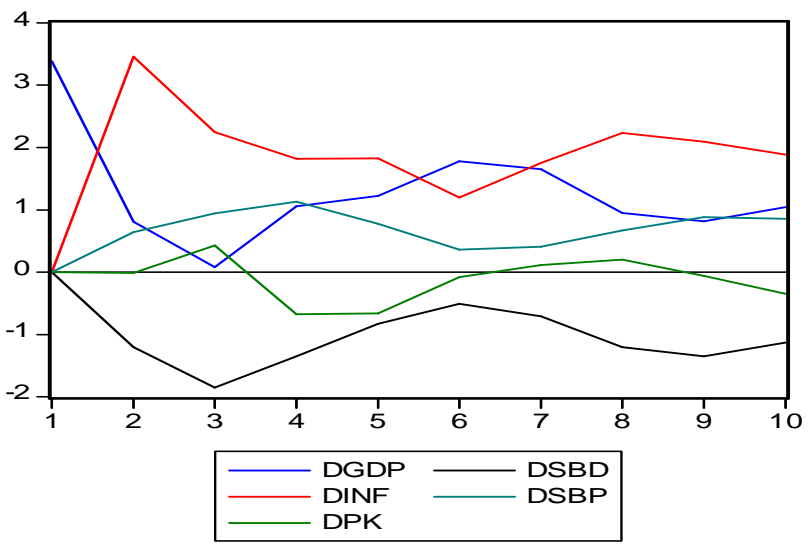

Figure 2: Impulse Response Function of Credit Channel to GDP

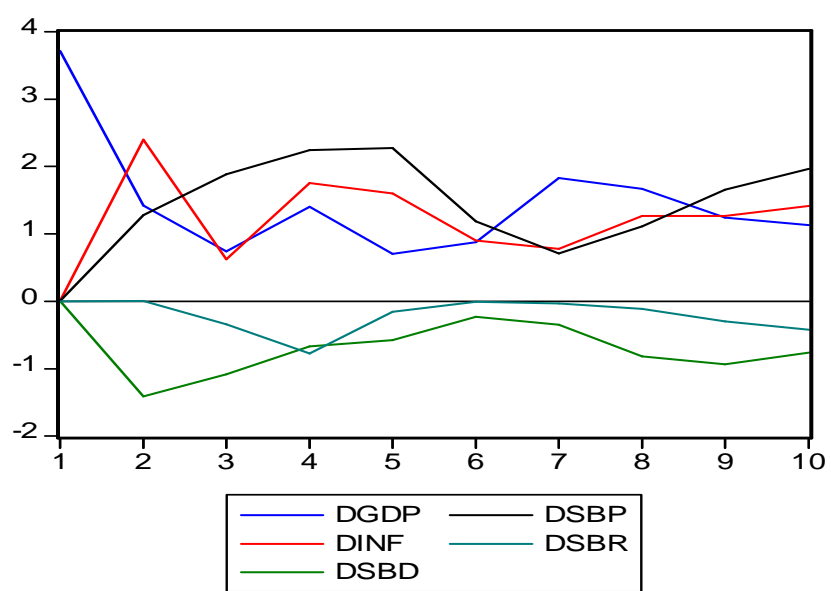

Figure 3: Impulse Response Function of Interest Rate Channel to GDP 
In Figure 3, GDP change due to the interest rate channel is caused by the GDP itself, INF, SBD, SBP and SBR. The effect of GDP, INF and SBP shocks are responded positively by GDP with the highest positive response value of $3.712788 \mathrm{SD}$ (GDP) in the period 1, $2.397059 \mathrm{SD}$ (INF) in period 2, and 2.275168 SD (SBP). While the shock SBD and SBR are responded negatively by GDP with the highest negative shock value of -1.412313 SD (SBD) in period 3 and $0.775669 \mathrm{SD}$ (SBR) in period 4. On average the interest rate responds to the shock in the period to two thus the interest rate channel is the second best monetary transmission of economic growth. It is quite reasonable due to a credit is closely related to interest rates as a factor that plays a major role in collecting and lending funds.

In Figure 4, GDP change due to the shock of exchange rate variables of GDP itself, EKS, IMP, INF, NT and SBR The shock of EKS, NT and INF are responded positively by GDP with the highest positive response value 1.200313 SD (EKS) in pe- riod 3, 0.793879 SD (INF) in period 3, and 1.258743 SD (NT). While the shock of IMP and SBR are responded negatively to GDP with the highest negative shock value of -3206583 SD (IMP) in period 4 and $0.484272 \mathrm{SD}$ (SBR) in period 2. The contribution of exchange rate to economic growth is more important since Indonesia is more exposed to international trade due to global production network entering the Community ASEAN economic (MEA).

Figure 5 shows the response of INF with respect to money shocks of GDP, INF itself, M2, and PK. Shock of M2 is responded positively by INF with the highest response value 5.747585 in period 3 . Thus each an increase in the money supply will increase the inflation rate. While the shocks of GDP and deposits are responded negatively by inflation with the highest value of 7.534999 SD (GDP) in the first period and $-0.199742 \mathrm{SD}(\mathrm{PK})$ in period 2. The fluctuation ends at period 5 and flat up to period of 10. Overall the inflation responds less to the money channel variables.

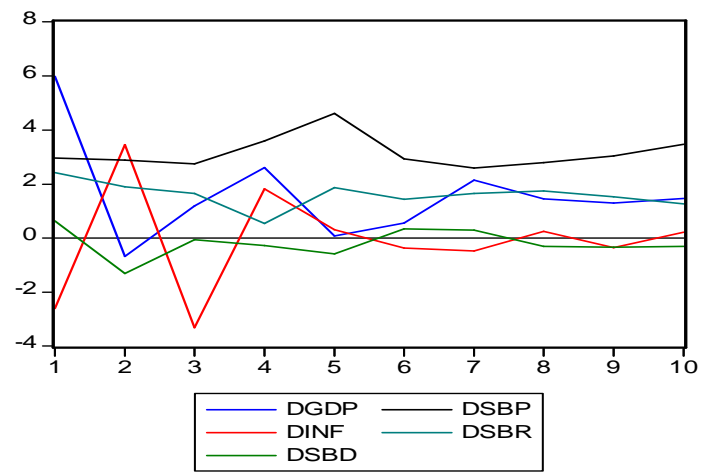

Figure 4: Impulse Response Function of Exchange Rate Channel to GDP

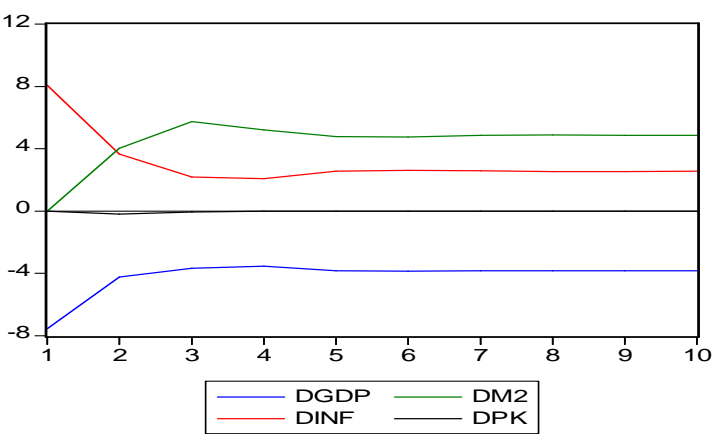

Figure 5: Impulse Response Function of Money Channel to Inflation 


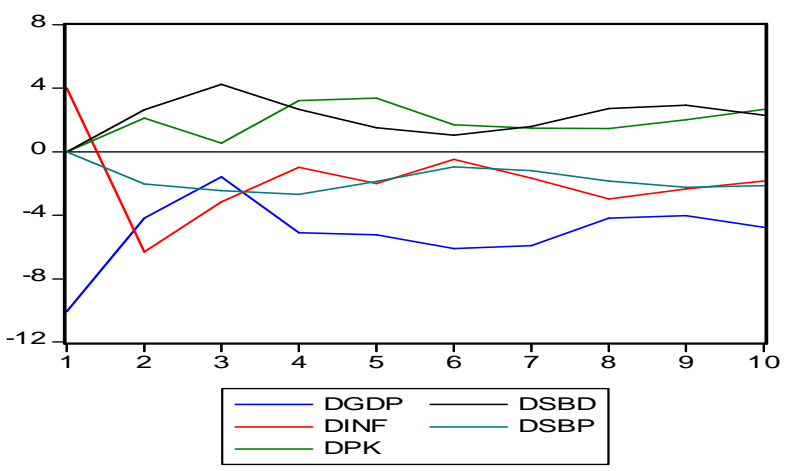

Figure 6: Impulse Response Function of Credit Channel to Inflation

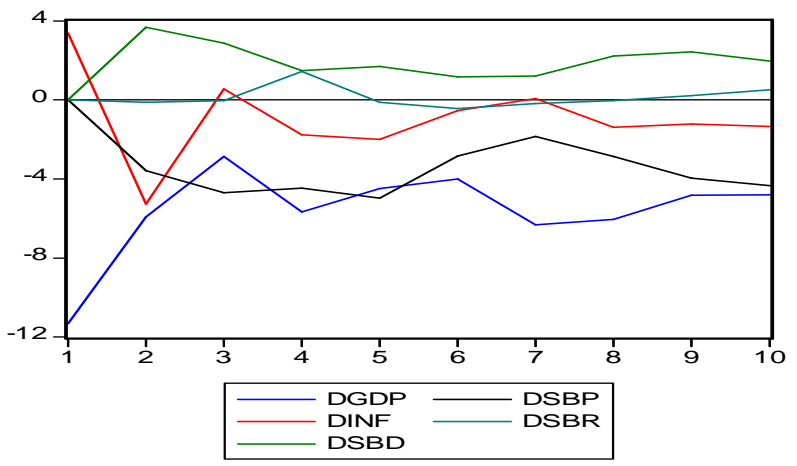

Figure 7: Impulse Response Function of Interest Rate Channel to Inflation

Figure 6 shows the response of inflation with respect to the shocks of GDP, SBR SBD, SBP and INF itself. Shock caused by SBD is responded positively by INF, where the value of the highest response is $3.669200 \mathrm{SD}$ (SBD) in period 2. Whereas GDP and SBP shocks are responded negatively by inflation with the highest value of -11.30537 SD (GDP) in period 1 and -4.684950 SD (SBP) in period 3 . Credit channels equally explain well the inflation in Indonesia.
Shock caused by SBD is responded positively by INF, where the value of the highest response is $3.669200 \mathrm{SD}$ (SBD) in period 2. Whereas the GDP and SBP shocks are responded negatively by inflation with the highest value of -11.30537 SD (GDP) in period 1 and -4.684950 SD (SBP) in period 3 . The money circulation Indonesia is less influenced by fluctuations of interest rates. All the variables of interest rates are responded in the early period, and continued to fluctuate up to period 10 (Figure 7).

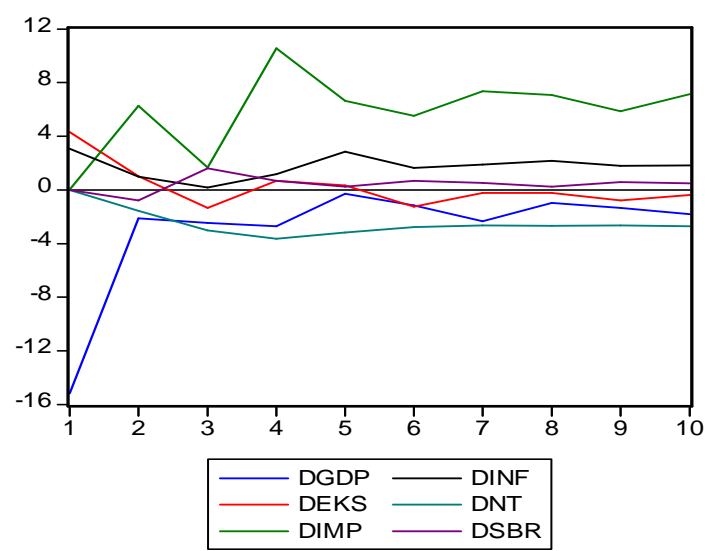

Figure 8: Impulse Response Function of Exchange Rate Channel to Inflation 
Figure 8 describes the shock caused by the GDP, EKS, IMP, INF, INF NT and SBR on the inflation. Shock caused by the IMP and SBR are positively responded by INF with the highest value of 7.353917 SD (IMP) in the period 7 and 1.619184 SD (SBR) in period 3. SBR shock is responded negatively by INF in the period 2 amounted -0.778411 SD. Shock caused by GDP and NT are also responded negatively by inflation with the lowest value of $-15.15940 \mathrm{SD}$ (GDP) in period 1 and -3.649581 SD (NT) in the period 4. EKS at the beginning of period 1 is positively responded of 4.297450 SD but at the end of period responded negatively to the lowest value of 1.3611359 SD in the period 3. It implies that inflation is less responsive to the exchange rate channel.

\section{Variance Decomposition}

Indicator for the strength of the response of each channel in explaining the ultimate targets also be seen from Test Variance Decomposition. (Cavoli, 2010). From the calculation of variance decomposition of money channels on GDP, the overall GDP can be explained by PK of $0.002432 \%$, INF of $6.479644 \%$, M2 of $1.549824 \%$ and GDP of $91.9681 \%$. As a whole the INF can be explained by PK of $0.008405 \%$, INF of $23.8563 \%$, M2 of $40.65936 \%$ and GDP of $35.47593 \%$.

Whereas the calculation of variance decomposition on credit channel on GDP found that the overall GDP can be explained by the INF of $49.03225 \%$, GDP of $27.81536 \%$, SBD of $15.16212 \%$, SBP of $6.47948 \%$ and GDP itself of $27.81536 \%$. The inflation can be explained by the INF $56.63786 \%$, INF of $17.05918 \%$, SBD of $11.12903 \%$, PK of $8.429563 \%$ and SBP of $6.744361 \%$.

The calculation of variance decomposition on interest rate channel show that the overall GDP can be explained by the GDP itself of $35.99171 \%$, SBP of $31.64206 \%$, INF of $23.18974 \%$, SBD of
$7.889052 \%$ and SBR of $1.287432 \%$. As a whole the INF can be explained by the INF of $60.89709 \%$, SBP of $22.46793 \%$, INF itself of $8.766766 \%$, SBD of $7.431392 \%$ and SBRf $0.436824 \%$.

For the exchange rate channels, the variance decomposition explains that the overall GDP can be explained by the IMP of $52.03556 \%$, GDP itself of $28.76549 \%$, EKS of $9.690739 \%$, NT of $7.429215 \%$, INF of $1.349348 \%$ and SBR of $0.729649 \%$. Meanwhile, the INF as a whole can be explained by IMP of $51.10847 \%$, GDP of $31.96951 \%$, NT of $8.726716 \%$, INF itself of $4.588184 \%$, EKS of $2.983701 \%$ and SBR of $0.623415 \%$.

\section{Monetary Policy Transmission Mechan- ism effective in Indonesia}

Indonesia's economic growth reached above $6 \%$ per year that it makes Indonesia is one of the countries with the highest growth rate and the most stable in the midst of global economic slowdown. Contributor to economic growth in Indonesia is none other than the increasing contribution of domestic demand amid declining export performance impact on weakening external demand. Robust domestic demand in Indonesia is largely derived from the level of household consumption that has been increasing since the global financial crisis in 2008/2009. The high level of consumption is largely financed with the credit. The more the credit is available, the higher is the economic growth. That is why the credit channels effectively explains the economic growth in Indonesia.

Indonesia which is currently also trying to increase the international trade exposure also keep the stable condition for the exchange rate. It looks increasingly intensive attention to maintain external balance and how to stabilize the exchange rate and re-stimulate exports in recent years to cover the current account deficit. This is also reflected in the exchange rate channel 
which in this study began to have an influence in explaining economic growth.

The inflation in Indonesia is well controlled at the level of $4.5 \%$. Inflation rate control is success because of policy coordination between the government and the central banks of Indonesia that is based on the five pillars

The first pillar is monetary policy. Monetary response through interest rate (BI Rate) is the main policy to steer inflation expectations to remain consistent with the objectives and taking into account economic growth. Interest rate structure is operating in harmony with the specified monetary liquidity and inflation in the shork term movements. Core inflation is becoming a major indicator in the formulation of monetary policy.

Second pillar is the exchange rate policy. Exchange rate policy will be directed to keep the movement of the exchange rate in accordance with the fundamental conditions. Exchange rate policies and the management of capital flows are directed as an integral part of achieving the inflation target. Management of the exchange rate under a free floating exchange rate regime is projected to maintain harmony between the movement of the exchange rate to the fundamentals. Stabilization of the exchange rate is the main instrument in the operation of exchange rate policy. Meanwhile, the management of capital flows remain to be done consistently with the free foreign exchange regime and directed to support the exchange rate policy. The increasing integration of the domestic economy with the global economy and the strong flow of foreign capital increases the complexity of macro-economic management, particularly monetary policy and exchange rate. In this respect it is necessary integration steps between exchange rate policies and management of foreign capital flows in response to monetary policy to achieve the inflation target which is taking into account the external balance.
Third pillar is macro-prudential policy. Macro prudential policy will be directed to the stability of the financial system and support the maintenance of intenal and external balance. Monetary response through interest rate (BI Rate) is the primary policy In this regard, a macroprudential is instrument support ( complement) of monetary instruments in achieving monetary stability and financial system, not as a substitute. Monetary and macroprudential instruments are used to maintain monetary stability and financial system as a whole, so that the monetary transmission through liquidity credit and asset price runs effectively in strengthening the transmission of interest rates, exchange rates and expectations. Monetary and macroprudential policies are designed to reinforce each other. Thus the policy coordination is necessary for the integration of the two policies in managing the economic cycle, strengthening the monetary policy transmission, and enhancing the resilience of the financial system as a macro to run well.

Fourth pillar is strengthening policy coordination. Bank Indonesia's policy coordination and the government, as well as other related parties, carried out in support of macroeconomic management, both in controlling inflation and the stability of the financial system. Policy coordination is done through controlling inflation by Inflation Control Team (TPI) at the central level, the Regional Inflation Control Team (TPID) in area and / or other coordination forums taken to control inflation, especially food prices stability (volatile food), mitigating the impact of price policy government against inflation (administered prices), increased production capacity, and demand management. Meanwhile, coordination in maintaining the stability of the financial system is done through the Financial Stability Coordination Forum (FKSSK).

Pillar 5 is strengthening communication policy. Strengthening communica- 
tion strategy policy is to manage inflation expectations. Communication is intended not only to support transparency, but rather as an instrument of monetary policy to steer public expectations in order to improve the effectiveness of monetary policy in the inflation target, reducing economic uncertainty, and improve transparency and public understanding of monetary policy

\section{Conclusion}

Indonesia is considered effective to use credit channel in influencing economic growth. This is because the growth of the Indonesian economy which largely supported by domestic economic activity, namely with the higher levels of consumption, is supported by loans provided by the banks. For inflation control problems found in Indonesia, Bank Indonesia still use interest rates as a tool to control the amount of money circulating in the economy to keep inflation stability as expected. Exchange rate channel starts to get important roles in many countries due to the exchange rate channels are directly related to the activities of international trade where exports and imports and the exchange rate is a key principle. Indonesia is a country with a small open economy which is highly depends on international market condition. Indonesia could focus on their international trade activities by giving special attention to the exchange rate channel in order to compete with theother countries.

\section{References}

Aban, M.J.A.C. (2013), "Transmission of monetary p0olicy through the bank lending channel in the Philippines," International Journal of Trade, Economics and Finance, 4(1), 3742.
Cavoli, T. (2010), "What drives monetary policy in post-crisis East Asia? interest rate or exchange rate monetary policy rules," Journal of Asian Economics, 21(5), 456-465

Chow, H.K. (2004), "A VAR analysis of Singapore's monetary transmission mechanism," SMU Economics and Statistics Working Paper Series, No. 19, Singapore Management University, Singapore.

Goeltom, M.S. (2008), "The transmission mechanisms of monetary policy in Indonesia," Bank for International Settlements (BIS) Papers, No.35, Switzerland.

Guinigundo, D.C. (2008), "Transmission mechanism of monetary policy in the Philippines," Bank for International Settlements (BIS) Papers, No.35, Switzerland.

Maski, G. (2007), Transmisi kebijakan moneter kajian teoritis dan empiris, Badan Penerbit Ekonomi Universitas Brawijaya, Malang.

Norman, L. And K. Schmidtz - Hebbel (2012), Monetary policy functions and transmission mechanism : an overview, Central Bank of Chile.

Poon, W.C. (2010), "Testing transmission mechanisms on economic growth in Malaysia," Department of Economics Discussion Paper, 26/10., Monash University. Malaysia

Wulandari, R. (2012), "Do credit channel and interest rate channel play important role in monetary transmission mechanism in Indonesia?: a structural vector autoregression model" Procedia - Social and Behavioral Science, 65(3), 557-563. 